\title{
Effect of Drying Methods on Phytochemical Composition of Orange Fruit (Citrus sinensis, L.) Peel Flour in Biscuit Making
}

\author{
${ }^{1}$ Rwubatse, Bernard, ${ }^{2}$ Akubor, Peter Issah and ${ }^{3}$ Mugabo, Emmanuel. \\ ${ }^{1,2}$ Departement of Food Science and Technology, University of Nigeria,Nsukka, Nigeria \\ 3. Departement of Food Science and Nutrition, University of Ghana, Legon, Ghana
}

\begin{abstract}
Sweet orange fruit (Citrus sinensis,L.) peels were dried to constant weight using oven, box solar and sun drying methods. The dried orange fruit peels were processed into flours and used to substitute 10,20 and 30 $\%$ wheat flour $(W F)$ in biscuits. The orange peel flours were analyzed for photochemical composition. The biscuits were analyzed for photochemical composition and evaluated for sensory properties. The content of flavanoids $(0.48 \mathrm{mg} / 100 \mathrm{~g})$ of the solar dried orange fruit peel flour (SOFPF), saponins $(0.73 \mathrm{mg} / 100 \mathrm{~g})$, tannins $(0.91 \mathrm{mg} / 100 \mathrm{~g})$ and alkaloids $(0.99 \mathrm{mg} / 100 \mathrm{~g})$ of oven dried orange fruit peel flour (ODOFPF) were higher than those of the sun dried orange fruit peel flour (SDOFPF). The carotenoids $(0.32 \mathrm{mg} / 100 \mathrm{~g})$, flavanoids $(0.38$ $\mathrm{mg} / 100 \mathrm{~g})$ of $30 \%$ SDOFPF biscuit, saponins $(0.33 \mathrm{mg} / 100 \mathrm{~g})$, tannins $(0.59 \mathrm{mg} / 100 \mathrm{~g})$ and alkaloids $(0.82$ $\mathrm{mg} / \mathrm{l00g}$ ) of the $30 \%$ ODOFPF based biscuit were higher than those of the other biscuits. The $100 \% \mathrm{WF}$ biscuit (control), followed by $10 \%$ SDOFPF biscuit had higher overall acceptability scores of 8.0 and 7.1, respectively than the other biscuits. The overall acceptability score of 5.5 for biscuit containing $30 \%$ ODOFPF was the lowest.
\end{abstract}

Keywords: Biscuit, Drying methods, Orange fruit peel flour, Phytochemicals

\section{Introduction}

World demand for phytochemicals such as flavonoids, alkaloids, and carotenoid is increasing. Thus, more food phytochemicals are required from both conventional and new sources [1]. Phytochemicals provide health benefits due to risk reduction of chronic illness such as cancer and cardiovascular diseases [2]. For instance, flavonoids have a wide range of biological effects such as inhibition of key enzymes in mitochondrial respiration, protection against coronary heart diseases, anti-inflammatory, anti-tumor and antimicrobial activities. [3]. It is therefore, necessary to explore ways for supplying phytochemicals in diets. A high percentage of orange fruit peels is rejected after eating or processing of orange fruits. The waste of these peels pollutes the environment. However, for food products to be utilized later, they need to be preserved. Several process technologies have been employed on an industrial scale to preserve food products; the major ones are canning, freezing and dehydration. Among these technologies, drying is especially suited for developing countries with poorly established low-temperature and thermal processing facilities. Drying offers a highly effective and practical means of preservation to reduce post-harvest losses and offset the shortages in supply. In direct solar drying called sun drying, the product is heated directly by the sun's rays and moisture is removed by natural circulation of air due to density differences. For solar drying, the moisture is taken away by the air entering into the cabinet from below and escaping through at the top exit. Solar drier reduces losses and contamination from insects, dust and animals. Solar driers protect food from sunlight, better preserving nutrients and color. Today's (modern) lifestyle has influenced food consumption habits worldwide where some foods such as baked products are eaten in offices, bus, classrooms, conference rooms etc. Baked foods especially, biscuits are among these ready to eat foods used at home. However, they contain a very limited amount of therapeutic substances (phytochemicals) and digestion facilating substances such as dietary fibers. These substances can be obtained through partial supplementation of wheat with flour prepared from orange fruit peels. These peels are rich in nutraceuticals and dietary fibers; to utilize them as food ingrdients is in the way of conducting waste management related to new food sources research and development. For this reason, this study was carried out to reduce the wastage of orange fruit peels by processing them into flour to supplement wheat flour in biscuit.

\subsection{Materials}

\section{Materials and Methods}

The materials in this study were ripe orange fruit peels and commercial wheat flour. The peels of sweet orange fruits were collected from orange juice processing plant and brought to the Food Science and Technology laboratory, University of Rwanda/College of Agriculture, Animal Sciences and Veterinary Medicine, Rwanda. The peels were cleaned in tap water, divided into three portions and dried to constant weight. One portion was dried in passive box solar drier at $38.5 \pm 8.6^{\circ} \mathrm{C}$ at air flow pressure lower than $1 \mathrm{mPa}$, 
another portion was dried in the oven at $50 \pm 1{ }^{\circ} \mathrm{C}$ at air flow pressure at lower than $1 \mathrm{mPa}$ and the third portion was sun dried at $16.5 \pm 5.5^{\circ} \mathrm{C}$ at wind movement pressure higher than $1 \mathrm{mPa}$. The dried peels were milled in an attrition mill and sieved through $0.2 \mathrm{~mm}$ mesh sieve. The peel flours from different drying methods were blended with wheat flour in the ratios of 10,20 and $30 \%$ and used to produce biscuits. The dried orange fruit peel flours and wheat flour were analyzed for phytochemical composition. The biscuits were evaluated for phytochemical composition and sensory properties.

\subsection{Analytical methods}

\subsubsection{Determination of phytochemical composition}

The determination of alkaloids and flavanoids in orange fruit peel flour and wheat flour were done as described by [4]. Determination of saponins was carried out as described by [5]. The tannins and carotenoids were determined as outlined by [6].

\subsubsection{Sensory evaluation of biscuits}

The biscuit samples were evaluated for sensory attributes of color, flavor, texture, taste, appearance and overall acceptability by trained 10-member panel, using a 9-point Hedonic scale where 1 represented dislike extremely and 9 like extremely [7].

2.2.3.Experimental design and statistical analysis

The experiment was $3 \times 3$ factorial design in randomized complete block (RCB). Data were subjected to one way analysis of variance (ANOVA) using SPSS (Statistical Package for the Social Sciences) software, version 20. Means with significant $(\mathrm{p}<0.05)$ differences were separated by the Least Significant Difference (LSD) test outlined [10].

\section{Results and Discussion}

\subsection{Phytochemical composition of orange fruit peel flour and wheat flour}

The effect of drying methods on the phytochemical composition of orange fruit peel flour is shown in Table 1 .

Table 1. Effect of drying methods on the phytochemical composition of orange fruit peel flours

\begin{tabular}{lllll}
\hline Phytochemical content & Wheat flour & \multicolumn{3}{c}{ Orange fruit peel flours } \\
\cline { 2 - 5 }$(\mathrm{mg} / 100 \mathrm{~g})$ & & Oven dried peel & Solar dried peel & Sun dried peel \\
\hline Carotenoids & $0.2^{\mathrm{b}} \pm 0.0$ & $0.3^{\mathrm{a}} \pm 0.03$ & $0.3^{\mathrm{a}} \pm 0.0$ & $0.3^{\mathrm{a}} \pm 0.015$ \\
Flavanoids & $0.22^{\mathrm{d}} \pm 0.01$ & $0.28^{\mathrm{c}} \pm 0.01$ & $0.48^{\mathrm{a}} \pm 0.01$ & $0.41^{\mathrm{b}} \pm 0.01$ \\
Saponins & $0.02^{\mathrm{d}} \pm 0.0$ & $0.73^{\mathrm{a}} \pm 0.02$ & $0.60^{\mathrm{b}} \pm 0.0$ & $0.50^{\mathrm{c}} \pm 0.1$ \\
Tannins & $0.20^{\mathrm{d}} \pm 0.01$ & $0.91^{\mathrm{a}} \pm 0.01$ & $0.78^{\mathrm{b}} \pm 0.025$ & $0.72^{\mathrm{c}} \pm 0.02$ \\
Alkaloids & $0.42^{\mathrm{d}} \pm 0.01$ & $0.99^{\mathrm{a}} \pm 0.085$ & $0.91^{\mathrm{b}} \pm 0.01$ & $0.81^{\mathrm{c}} \pm 0.02$ \\
\hline
\end{tabular}

Values are means \pm SD of 3 replications. Means within a row with the same superscript were not significantly (p $>0.05$ ) different

The drying methods affected significantly $(p>0.05)$ the flavanoids, saponins, tannins and alkaloids contents of orange peel flours with oven drying exerting lesser effect. However, the carotenoids were not significantly $(\mathrm{p}>0.05)$ affected by oven, solar and sun drying methods as the content remained $0.3 \mathrm{mg} / 100 \mathrm{~g}$ for all of the orange peel flours. Similar observation was also reported [8]. The solar dried orange peel flour, followed by sun dried orange peel flour, had higher level of flavanoids $(0.48 \mathrm{mg} / 100 \mathrm{~g}$ and $0.41 \mathrm{mg} / 100 \mathrm{~g}$, respectively) than that of oven dried orange fruit peel flour $(0.28 \mathrm{mg} / 100 \mathrm{~g})$. The low level of flavanoids for oven dried orange fruit peel flour may have been caused by the high temperature treatment used in the oven drying. The loss of macromolecules like flavonoids during heat treatment might be due to the harsh drying conditions, in particular, the temperature used [9]. Contrarily, the levels of saponins, tannins and alkaloids which were 0.73 $\mathrm{mg} / 100 \mathrm{~g}, 0.91 \mathrm{mg} / 100 \mathrm{~g}$ and $0.99 \mathrm{mg} / 100 \mathrm{~g}$, respectively, were higher in the oven dried orange fruit peel flour than those of solar and sun dried orange fruit peel flours. This may be attributed to the absence of sunlight and low oxygen in the oven which may have favoured the formation and development of saponins, tannins and alkaloids in the orange peel tissue. The thermal processing can affect the phytochemicals by thermal breakdown that affect the integrity of the cell structure which then results in the migration of components, leading to losses by leakage or breakdown by various chemical reactions involving enzymes, light and oxygen [10].

\subsection{Phytochemical composition of biscuits}

The phytochemical composition of biscuits supplemented with orange fruit peel flour is shown in Table 2

Table 2. Phytochemical composition of biscuits supplemented with orange fruit peel flour 
Effect of Drying methods on Phytochemical Composition of Orange Fruit .....

\begin{tabular}{|c|c|c|c|c|c|c|c|}
\hline Drying methods & Biscuits & WF : OPF & $\begin{array}{l}\text { Carotenoids } \\
(\mathrm{mg} / 100 \mathrm{~g})\end{array}$ & $\begin{array}{l}\text { Flavanoids } \\
(\mathrm{mg} / 100 \mathrm{~g})\end{array}$ & $\begin{array}{l}\text { Saponins } \\
(\mathrm{mg} / 100 \mathrm{~g})\end{array}$ & $\begin{array}{l}\text { Tannins } \\
(\mathrm{mg} / 100 \mathrm{~g})\end{array}$ & Alkaloids (mg/100g) \\
\hline & & $100: 0$ & $0.16^{d}=0.03$ & $0.18 z=0.01$ & $0.01^{f}=0.0$ & $0.14 z=0.02$ & $0.34 \mathrm{~g}=0.01$ \\
\hline \multirow[t]{4}{*}{ Oven } & WF:ODOFPF & $90: 10^{-}$ & $0.18^{\mathrm{a}}=0.01^{-}$ & $0.20 \mathrm{~s}=0.0^{\circ}$ & $0.24^{\mathrm{ca}}=0.02$ & $0.43=0.01$ & $0.75^{6}=0.0^{-}$ \\
\hline & & $80: 20$ & $0.23^{\mathrm{c}}=0.01^{--}$ & $0.24^{f}=0.03^{-1}$ & $0.27^{60}=0.03$ & $0.53^{\circ}=0.01^{-}$ & $0.76^{6}=0.01$ \\
\hline & & $70: 30$ & $0.29^{\circ}=0.01^{-}$ & $0.28^{\circ}=0.01$ & $0.33^{\mathrm{i}}=0.03^{-1}$ & $0.59:=0.05$ & $0.82^{\mathrm{s}}=0.02$ \\
\hline & & $100: 0^{-}$ & $0.16^{a}=0.03^{-1}$ & $0.18 \bar{s}=0.05$ & $0.01^{1}=0.0^{-}$ & $0.145=0.02$ & $0.34=0.01^{-1}$ \\
\hline \multirow[t]{4}{*}{ Solar } & WF:SOFPF & $90: 10^{-1}$ & $0.18^{\mathrm{a}}=0.04^{--}$ & $0.30^{\mathrm{d}}=0.02$ & $0.2 \mathrm{r}^{\mathrm{a}}=0.01$ & $0.30^{\circ}=0.01$ & $0.55=0.01$ \\
\hline & & $80: 20^{--}$ & $0.24^{e}=0.03^{--}$ & $0.33^{\mathrm{ca}}=0.03^{-}$ & $0.23^{\mathrm{cd}}=0.03^{-}$ & $0.38=0.02$ & $0.56=0.04$ \\
\hline & & $70: 30^{--}$ & $0.30^{2}=0.0^{---}$ & $0.36^{36}=0.02$ & $0.29 \mathrm{~s}=0.01$ & $0.444^{\circ}=0.04$ & $0.62=0.02$ \\
\hline & & $100: 0$ & $0.16^{\mathrm{a}}=0.03^{--}$ & $0.18 \bar{s}=0.01$ & $0.01^{\mathrm{f}}=0.0^{--}$ & $\gamma .14 \mathrm{~s}=0.02$ & $0.34 \mathbf{s}^{-}=0.0 \mathrm{1}^{-}$ \\
\hline \multirow[t]{3}{*}{ Sun } & WF:SDOFPF & $90: 10^{--}$ & $0.18^{\mathrm{a}}=0.02^{-}$ & $0.31 \mathrm{da}=0.01$ & $0.18 \div=0.0$ & $0.17=0.02$ & $0.34 \mathrm{~s}=0.04^{-}$ \\
\hline & & $80: 20$ & $0.25^{60}=0.03^{-}$ & $0.34^{66}=0.02$ & $0.20^{36}=0.01$ & $0.23^{\prime}=0.03^{-\cdots}$ & $0.42 f=0.02$ \\
\hline & & $70: 30$ & $0.32 \mathrm{z}=0.02^{--}$ & $0.38^{\mathrm{i}}=0.01^{-1}$ & $0.26^{66}=0.06$ & $0.29 \cdot=0.01$ & $0.48=0.0$ \\
\hline
\end{tabular}

Values are means \pm SD of 3 replications. Means within a row with the same superscript were not significantly (p $>0.05$ ) different.WF: Wheat flour, OPF: Orange fruit peel flour, ODOFPF: Oven dried orange fruit peel flour, SOFPF: Solar dried orange fruit peel flour, SDOFPF: Sun dried orange fruit peel flour.

The phytochemicals significantly increased in biscuits with increase in the addition of orange peel flour in the blends due to addition effect (Table 1). However, the carotenoid content of $10 \%$ ODOFPF, $10 \%$ SOFPF and 10 $\%$ SDOFPF biscuits were not significantly $(\mathrm{p}>0.05)$ different from that of $100 \% \mathrm{WF}$ biscuit. The amounts of carotenoids $(0.32 \mathrm{mg} / 100 \mathrm{~g})$ and flavanoids $(0.38 \mathrm{mg} / 100 \mathrm{~g})$ for $30 \%$ SDOFPF biscuit were the highest. Carotenoids are anti-oxidants, important anti-aging, enhance immune function, balance blood sugars and reduce risk of cardiovascular diseases and cancers (especially prostate and lung cancers). Flavanoids are anti-oxindats, lower cholesterol, inhibit tumor formation, decrease inflammation and protect against cancer, heart disease [2]. The contents of saponin $(0.33 \mathrm{mg} / 100 \mathrm{~g})$, tannin $(0.59 \mathrm{mg} / 100 \mathrm{~g})$ and alkaloid $(0.82 \mathrm{mg} / 100 \mathrm{~g})$ were higher in 30 $\%$ ODOFPF biscuit than those of other biscuits. The lowest levels of saponin $(0.18 \mathrm{mg} / 100 \mathrm{~g})$, tannin $(0.17$ $\mathrm{mg} / 100 \mathrm{~g})$ and alkaloid $(0.34 \mathrm{mg} / 100 \mathrm{~g})$ were in the $10 \%$ SDOFPF based biscuit. The saponin and tannin contents of $10 \%$ SDOFPF biscuit were not significantly ( $p>0.05)$ different from those of $100 \%$ WF biscuit. Saponins have hypolipidemic and anticancer activity, antioxidant and anti-mutagenic properties and are also necessary for activity of cardiac glycosides [11]. Tannins are used as antiseptic. Tannin rich medicinal plants are used as healing agents for a number of diseases like leucorrhoea, rhinnorhoea and diarrhea [12]. Alkaloids have pharmacological applications as anesthetics and Central Nervous System (CNS) stimulants, muscle relaxant, antibiotics, anti-cancer, anti-arrythmic and sedative [13]. The increase in alkaloids, saponins, tannins content in supplemented biscuits was also reported [14].

\section{3. Sensory properties of biscuits}

The sensory properties of biscuits supplemented with orange fruit peel flour are given in Table 3

Table 3. Sensory properties of biscuits supplemented with orange fruit peel flour

\begin{tabular}{|c|c|c|c|c|c|c|c|c|}
\hline $\begin{array}{l}\text { Drying } \\
\text { methods }\end{array}$ & Biscuits & WF : OPF & Color & Flavor & Taste & Texture & Appearance & $\begin{array}{l}\text { Overall } \\
\text { acceptability }\end{array}$ \\
\hline \multirow{4}{*}{ Oven } & WF:ODOFPF & $\begin{array}{l}100: 0 \\
90: 10\end{array}$ & $\begin{array}{l}6.8^{2}=0.2 \\
6.8^{2}=1.3\end{array}$ & $\begin{array}{l}8.6^{2}=0.2 \\
6.7^{68}=0.11\end{array}$ & $\begin{array}{l}7.2^{2}=0.2 \\
6^{-7}=0.2^{2}\end{array}$ & $\begin{aligned} 7.7^{2} & =0.4 \\
66^{6} & =0.2\end{aligned}$ & $\begin{aligned} & 7.9 a=0.9 \\
& 68^{20}=0.2\end{aligned}$ & $8.0^{2}=2.0$ \\
\hline & & $80: 20$ & $6.4^{\mathrm{ab}}=0.1^{-}$ & $5.6^{\mathrm{ca}}=0.3$ & $6.4^{2}=0.2^{2}$ & $6.2^{\mathrm{a}}=0.4^{-}$ & $6.2^{\mathbf{a} 6}=0.2$ & $6.4^{\mathrm{b}}=0.2^{2}$ \\
\hline & & $70: 30$ & $5.7^{6}=0.2$ & $4.6^{x}=0.2^{-2}$ & $5.0^{6}=0.0^{-}$ & $5.8^{\mathrm{a}}=0.2^{--}$ & $6.8^{20}=0.10^{-}$ & $5.5^{\circ}=0.1^{-}$ \\
\hline & & $100: 0$ & $6.8^{2}=0.2^{-}$ & $8.6^{6}=0.2^{-}$ & $7.2^{\mathrm{a}}=0.2^{-}$ & $7.7^{2}=0.4^{-}$ & $79^{\circ}=0.90^{\circ}$ & $8.0^{\circ}=2.0^{\circ}$ \\
\hline \multirow[t]{4}{*}{ Solar } & WF:SOFPF & $90: 10$ & $6.6^{16}=0.0$ & $7.4^{6}=0.4^{-}$ & $6.9^{2}=0.1$ & $7.4^{2}=0.1^{1}$ & $7.5^{2}=0.20^{-}$ & $7.0^{26}=2.0^{\circ}$ \\
\hline & & $80: 20$ & $6.5^{20}=0.3^{3}$ & $6.0^{\circ}=2.0^{\circ}$ & $6.6^{\mathrm{i}}=0.1^{-1}$ & $6.8^{\circ 0}=0.4^{-}$ & $6.8^{\mathrm{a} b}=0.1^{-}$ & $6.6^{20}=0.1$ \\
\hline & & $70: 30$ & $5.7^{\circ}=0.7^{\circ}$ & $5.6^{60 \mathrm{~s}}=0.6$ & $6.0^{16}=2.0$ & $6.6^{\circ}=0.0^{-}$ & $5.8^{\circ}=0.3^{\circ}$ & $5.6^{\circ}=0.1^{-}$ \\
\hline & & $100: 0$ & $6.8^{2}=0.2^{-}$ & $8.6^{2}=0.2^{-}$ & $7.2^{\mathrm{i}}=0.2^{-}$ & $7.7^{2}=0.4^{4}$ & $7.9^{2}=0.9$ & $8.0^{2}=2.0^{\circ}$ \\
\hline \multirow[t]{3}{*}{ Sun } & WF:SDOFPF & $90: 10^{-}$ & $6.8^{2}=0.6^{-6}$ & $7.4^{6}=0.1^{-}$ & $7.0^{2}=1.0^{\circ}$ & $7.2^{26}=0.2$ & $6.9^{20}=0.2$ & $7.1^{16}=0.1$ \\
\hline & & $80: 20^{-}$ & $6.5^{3 b}=0.1^{-}$ & $6.5^{60}=0.1$ & $6.5^{2}=0.0^{-}$ & $6.6^{c}=0.2^{-}$ & $6.5^{\mathrm{a} 6}=0.2^{-}$ & $6.7^{26}=0.1$ \\
\hline & & $70: 30$ & $6.4^{20}=0.4^{3}$ & $6.4^{60}=0.2$ & $6.2^{\mathrm{i}}=0.2^{-}$ & $6.3^{\mathrm{ca}}=0.3^{-}$ & $6.0^{30}=3.0$ & $6.0^{20}=1.0^{2}$ \\
\hline
\end{tabular}

Values are means \pm SD of 7 replications. Means within a row with the same superscript were not significantly (p $>0.05$ ) different.WF: Wheat flour, OPF: Orange fruit peel flour, ODOFPF: Oven dried orange fruit peel flour, SOFPF: Solar dried orange fruit peel flour, SDOFPF: Sun dried orange fruit peel flour.

The overall acceptability score of 8.0 for the $100 \%$ WF biscuit was the highest and followed by 7.1 for the biscuit containing $10 \%$ SDOFPF. The overall acceptability score (5.5) for biscuit containing $30 \%$ ODOFPF was the lowest. Generally, the preference for the biscuits by panelists was associated with the low level of 
bitterness. It is the reason why $100 \%$ WF biscuit received the highest score as it was less bitter than other biscuits. The astringent taste and bitterness encountered in biscuits were caused by the alkaloids, tannins and saponins in the orange fruit peel [15].

\section{Conclusion}

The drying methods affected the quality of flours and biscuits prepared from the peels of sweet orange fruits (Citrus sinensis, L.). The oven, solar and sun dried orange fruit peel flours were significantly $(p<0.05)$ different in phytochemical composition. The oven dried orange peel flour had higher amounts of alkaloids, tannins and saponins than the other dried orange peel flours. The oven, solar and sun dried orange peel flours contained higher levels of flavanoids, tannins, saponins and alkaloids than wheat flour. The supplemented biscuits had higher amounts of carotenoids, flavanoids, saponins, tannins and alkaloids than $100 \%$ wheat flour biscuit (control). The $100 \%$ wheat flour biscuit, followed by the biscuit containing $10 \%$ sun dried orange peel flour were the most organoleptically preferred biscuits. The overall acceptability score for biscuit containing $30 \%$ ODOFPF was the lowest. The use of flour from orange fruit peels dried by oven, solar and sun drying methods improved the phytochemical composition and sensory characteristics of the biscuit.

\section{References}

[1]. S. Ersus and M. Cam, Determination of organic acids, total phenolic content and antioxidant capacity of sour citrus aurantium fruits, Chemistry of Natural Compounds, 43 (5), 2007, 607-609.

[2]. I. A. Onimawo and P. I. Akubor, Food chemistry. Integrated approach with biochemical background (Ibadan, Nigeria, Joytal printing press, 2012) $287-290$

[3]. A. Kar, Pharmaocgnosy and Pharmacobiotechnology (Revised-Expanded $2^{\text {nd }}$ Edn, New Delhi, New Age International Limted Publishres, 2007) 332-338.

[4]. J. R. Harbone, Phytochemical methods: A guide to modern techniques of plant analysis (Chapman and Hall Ltd London, 1973) 4955.

[5]. A. O. A.C, Official methods of analysis 17th Ed, (Association of Official Analytical Chemists, Washington, D.C., USA, 2010)

[6]. [8]H. Kirk and R. Sawyer, Frait Pearson chemical analysis of foods $\left(9^{\text {th }}\right.$ edn., Longman Scientific and Technical, Edinburgh, 1998) $211-212$

[7]. O. Alexandra, Sensory evaluation of foods, (http://en.wikipedia.org/wiki/Senses, 15 April, 2011).

[8]. R.G. Steel and J. H. Torrie, Principles and procedure of statistics: A biometrical approach ( $2^{\text {nd }}$ edn. Mc-Graw-Hill Publisher, New York, 1980) 34-44.

[9]. A. Bengtson, A. Namutebi, M. Larssonalminger and U. Svanberg, Effects of various traditional processing methods on the all-transbeta-carotene content of orange fleshed sweet potato, Journal of Food Composition and Analysis 21, 2008,134-143.

[10]. A. Schieber, P. Keller and R. Carle, Determination of phenolic acids and flavonoids of apple and pear by high-performance liquid chromatography, Journal of Chromatography A, 910, 2001, 265-273.

[11]. M.P.Mattson and A.Cheng, Neurohormetic phytochemicals: lowdose toxins that induce adaptive neuronal stress responses, Trends in Neurosciences, 11, 2006, 632-639.

[12]. C.O.Eleazu, S.Kolawole and E.Awa, Phytochemical composition and antifungal actions of aqueous and ethanolic extracts of the peels of two yam varieties, Medecinal and Aromatic Plants, 2013, DOI: 10.4172/2167-0412.1000128.

[13]. H.A.Madziga, S.Sanni and U.K.Sandabe, Phytochemical and elemental analysis of acalypha wilkesiana leaf, Journal of American Science, 11,2010 510-514.

[14]. M. N. Akpu and L.C. Okpala, Effect of orange peel flour on the quality characteristics of bread, British Journal of Applied Science and Technology, 4(5), 2014, 823-830.

[15]. P. C. Chikezie, E. N. Agomuo and B. A. Amadi, Biochemistry, Practical/Research Method, A Fundamental Approach (Nigeria, Mega soft publishers, 2008) 51-53. 